\title{
Current management of non-alcoholic fatty liver disease
}

\author{
Quelson Coelho Lisboa ${ }^{1 *}$, Silvia Marinho Ferolla Costa² ${ }^{2}$ Cláudia Alves Couto ${ }^{3}$ \\ ${ }^{1}$ MD, MSc in Sciences Applied to Adult Health with an emphasis on Gastroenterology, Instituto Alfa de Gastroenterologia, Hospital das Clínicas da Universidade Federal de Minas Gerais (UFMG), Belo Horizonte, MG, Brazil \\ ${ }^{2}$ Nutritionist, PhD in Sciences Applied to Adult Health, Instituto Alfa de Gastroenterologia, Hospital das Clínicas da UFMG, Belo Horizonte, MG, Brazil \\ ${ }^{3} \mathrm{MD}, \mathrm{PhD}$ in Gastroenterology. Associate Professor, Faculdade de Medicina da UFMG, Instituto Alfa de Gastroenterologia, Hospital das Clínicas da UFMG, Belo Horizonte, MG, Brazil
}

Study conducted at Instituto Alfa de Gastroenterologia, Hospital das Clínicas da Universidade Federal de Minas Gerais

(UFMG), Belo Horizonte, MG, Brazil

Article received: $12 / 23 / 2015$ Accepted for publication: 1/17/2016

*Correspondence: Address: Av. Professor Alfredo Balena, 110, Belo Horizonte, MG - Brazil Postal code: 30130-100 quelsoncoelho@gmail.com

http://dx.doi.org/10.1590/1806-9282.62.09.872

\section{SUMMARY}

Non-alcoholic fatty liver disease (NAFLD) is characterized by hepatic accumulation of lipid in patients who do not consume alcohol in amounts generally considered harmful to the liver. NAFLD is becoming a major liver disease in Eastern countries and it is related to insulin resistance and metabolic syndrome. Treatment has focused on improving insulin sensitivity, protecting the liver from oxidative stress, decreasing obesity and improving diabetes mellitus, dyslipidemia, hepatic inflammation and fibrosis. Lifestyle modification involving diet and enhanced physical activity associated with the treatment of underlying metabolic are the main stain in the current management of NAFLD. Insulin-sensitizing agents and antioxidants, especially thiazolidinediones and vitamin E, seem to be the most promising pharmacologic treatment for non-alcoholic steatohepatitis, but further long-term multicenter studies to assess safety are recommended.

Keywords: non-alcoholic fatty liver disease, steatosis, steatohepatitis, metabolic syndrome, obesity.

\section{INTRODUCTION}

Non-alcoholic fatty liver disease (NAFLD) is a clinical/ pathological condition characterized by significant lipid deposition in the hepatocytes (steatosis) after the exclusion of significant alcohol intake, viral infection, or other specific liver disease. Steatosis is usually diagnosed using imaging examinations, which may or not be associated with necroinflammatory changes and fibrosis (steatohepatitis) diagnosed by liver biopsy. This disease encompasses a spectrum of changes ranging from steatosis and steatohepatitis to fibrosis and hepatic cirrhosis, and is associated with a higher frequency of hepatocellular carcinoma. ${ }^{1,2}$

NAFLD is considered the hepatic manifestation of metabolic syndrome (MetS), ${ }^{1}$ which is defined by the presence of at least three of the following factors: central obesity, hypertension, hypertriglyceridemia, reduced highdensity lipoprotein (HDL) cholesterol, and hyperglycemia. ${ }^{2}$ The strong association between NAFLD and insulin resistance (IR) and MetS is well documented in the literature. ${ }^{3}$ This condition is currently recognized as the most prevalent liver disease in Western populations with average rates estimated at 20 to $30 \%$.

\section{TREATMENT OF NAFLD}

NAFLD treatment aims to reduce insulin resistance and oxidative stress, control the associated conditions (obesity, diabetes mellitus, dyslipidemia), and also reduce inflammation and fibrosis of the liver. Considering all patients with NAFLD, the treatment focuses on lifestyle modifications, including a change of eating habits and the regular practice of physical activities, associated with the treatment of all the components of metabolic syndrome. Discontinuation of the use of hepatotoxic drugs is also recommended.

Patients with non-alcoholic steatohepatitis (NASH) should be the main target of treatment given that this group has a higher risk of mortality related to the disease. Among the causes of death in patients with NASH, cardiovascular diseases are in first place, followed by complications from cirrhosis and hepatocellular carcinoma. The ideal management of these patients is not yet well established. Clinical trials currently in progress are focusing on this population. Lifestyle modifications with diet and physical activity, bariatric surgery, drug therapy to improve IR and the use of antioxidants are the therapies 
that have been studied the most. Other treatment approaches have aimed at inhibiting proinflammatory or fibrotic pathways. ${ }^{4,5}$

\section{Diet AND PHYSICAL ACTIVITY}

NAFLD is a manifestation of obesity and of MetS, usually associated with excess calorie intake and a lack of physical activity. Weight loss is widely accepted as part of treatment for patients with NAFLD, although there is still a lack of data to provide guidance on how, in what amount of time and how much weight the patient should lose. ${ }^{6,7}$ The lack of data makes it difficult to elaborate evidence-based recommendations for the modification of diet and the practice of physical exercise in the treatment of NAFLD. It is recommended to perform exercises for at least 250 minutes per week. ${ }^{8}$ In general, 5 to $10 \%$ reduction in body weight in obese or overweight people over 6 to 12 months has been advocated through changes to eating habits and the practice of physical activity. This recommendation is based on short-term studies that showed an improvement in IR and in liver histology with gradual weight loss, as shown in Table 1.

\section{BARIATRIC SURGERY}

In patients with morbid obesity or obese patients of greater severity (BMI $>40$ or BMI between 35 and 40 with comorbidities), bariatric surgery induces long-term maintenance of weight loss and has been recommended by the researchers for motivated candidates. Whatever the surgical procedure, 14 to $25 \%$ weight loss is observed 10 years after surgery, associated with improvement in IR, remission of diabetes mellitus and few cardiovascular events. ${ }^{15,16}$

In terms of liver damage, various studies have shown improvement of the steatosis after bariatric surgery. A meta-analysis in 2008 that included 15 studies and 766 paired liver biopsies of patients undergoing bariatric surgery showed significant improvement of all NAFLD components: reduction of steatosis in $93 \%$, reduction of steatohepatitis in $82 \%$ and reduction of fibrosis in $73 \% .{ }^{17}$ Other recent studies have suggested potential benefits of

TABLE 1 Recently published clinical trials on the effect of diet associated with physical activity in patients with NAFLD.

\begin{tabular}{|c|c|c|c|c|}
\hline Author/year & Diagnosis & $\mathbf{n}$ & Intervention & Results \\
\hline $\begin{array}{l}\text { Baba et al., } \\
2006^{9}\end{array}$ & Biopsy & 65 & $\begin{array}{l}\text { Moderate calorie restriction in obese individuals + PA ( } 40 \text { ' } \\
\text { walk 3-4 times per week, } 60 \text { to } 70 \% \text { maximum HR) }\end{array}$ & $\begin{array}{l}\text { Beneficial effect limited to } \\
\text { patients who fulfilled the dietary } \\
\text { programs and PA }(n=44)\end{array}$ \\
\hline $\begin{array}{l}\text { Thamer et al., } \\
2007^{10}\end{array}$ & MRI & 112 & $\begin{array}{l}\text { Reduction of fat intake up to } 30 \% \text { of total calories, } \\
\text { reduction of saturated fatty acids up to } 10 \% \text { of total } \\
\text { calories, increased daily dose of fiber intake to } 15 \mathrm{~g} / 1,000 \\
\mathrm{kcal} \text {, and increased PA to } 3 \mathrm{~h} / \text { week for } 9 \text { months }\end{array}$ & Reduction of IR and fat in the liver \\
\hline $\begin{array}{l}\text { Albu et al., } \\
2010^{11}\end{array}$ & MRI & 58 & $\begin{array}{l}\text { Decreased calorie intake (-500 kcal/day) and increased PA } \\
(\geq 175 \mathrm{~min} / \text { week), during } 12 \mathrm{months}\end{array}$ & $\begin{array}{l}\text { Reduction of fasting blood } \\
\text { glucose and fat in the liver }\end{array}$ \\
\hline $\begin{array}{l}\text { Promrat et al., } \\
2010^{12}\end{array}$ & Biopsy & 65 & $\begin{array}{l}\text { Caloric restriction (1,000-1,200 kcal/day if baseline weight } \\
<200 \mathrm{lb} \text { or 1,200-1,500/day if initial weight }>200 \mathrm{lb}) \text { and a } \\
\text { daily fat target of } 25 \% \text { and } 200 \text { minutes of moderately } \\
\text { intense PA per week for } 12 \text { months }\end{array}$ & $\begin{array}{l}\text { Significant improvement in } \\
\text { steatosis, lobular inflammation, } \\
\text { hepatocyte ballooning and NAS in } \\
\text { patients with a decrease of at least } \\
7 \% \text { of total body weight }\end{array}$ \\
\hline $\begin{array}{l}\text { Lazo et al., } \\
2010^{13}\end{array}$ & MRI & 5,145 & $\begin{array}{l}\text { Moderate caloric restriction }(1,200-1,500 \mathrm{kcal} / \text { day for } \\
\text { individuals weighing }<114 \mathrm{~kg} \text { and } 1,500-1,800 \mathrm{kcal} / \text { day } \\
\text { for those weighing }>114 \mathrm{~kg}) \text { and increased physical } \\
\text { activity with a target of } 175 \text { min of moderately intense PA } \\
\text { per week for } 12 \text { months }\end{array}$ & Reduction in liver fat \\
\hline $\begin{array}{l}\text { Oh et al., } \\
2014^{8}\end{array}$ & Fibroscan & $\begin{array}{l}169 \\
\text { (obese) }\end{array}$ & $\begin{array}{l}\text { Calorie restriction of } 1,680 \mathrm{kcal} / \text { day and PA for less than } \\
250 \text { min per week or } 250 \mathrm{~min} \text { or more per week }\end{array}$ & $\begin{array}{l}\text { Reduction of serum ferritin and } \\
\text { adiponectin and reduction of liver } \\
\text { fat }\end{array}$ \\
\hline $\begin{array}{l}\text { Vilar-Gomez et } \\
\text { al., } 2015^{14}\end{array}$ & Biopsy & 293 & $\begin{array}{l}\text { Low-calorie diet ( } 750 \mathrm{kcal} / \text { day less than the calculated } \\
\text { daily energy need) and PA for } 200 \text { min a week for } 52 \text { weeks }\end{array}$ & $\begin{array}{l}\text { Histological improvement, } \\
\text { including fibrosis, when weight loss } \\
\text { was greater than or equal to } 10 \%\end{array}$ \\
\hline
\end{tabular}

PA: physical activity; HR: heart rate; NAS: NAFLD Activity Score; MRI: magnetic resonance imaging. 
bariatric surgery. ${ }^{18-21}$ However, there is a lack of randomized studies assessing the effect of this procedure on NASH. Therefore, performing bariatric surgery specifically for the treatment of this condition is not recommended. ${ }^{22}$ It should be considered that although bariatric surgery may play a role in the treatment of patients with morbid obesity and NASH, the recommendation of this procedure must be individualized and conducted at specialized medical centers with a multidisciplinary approach due to the potential complications, which vary depending on the center where the procedure is performed (mean mortality of $0.3 \%$ and morbidity of $10 \%$ ).

\section{Antioxidants}

Antioxidants, especially vitamin E, have been studied in patients with NAFLD because oxidative stress is considered a key mechanism in the pathophysiology of NASH, leading to hepatocellular injury and progression of the disease.

\section{Vitamin $\mathrm{E}$}

Vitamin $\mathrm{E}$ is a fat-soluble vitamin with antioxidant properties. Two recently published, large-scale, randomized and controlled studies (PIVENS and TONIC) have assessed its effect on NAFLD in adults and children, respectively. ${ }^{23,24}$ In the PIVENS study, a significant histological improvement (a reduction of at least 2 points in the inflammatory activity score - NAS) was noted in patients who received vitamin $\mathrm{E}$ compared to patients treated with a placebo (43 vs. $19 \%, \mathrm{p}=0.001){ }^{23}$ In children with hepatic steatosis, both vitamin $\mathrm{E}$ associated with metformin and the isolated use of vitamin $\mathrm{E}$ were not superior to the placebo in reducing alanine aminotransferase (ALT) levels in the TONIC study. However, the children treated with vitamin $\mathrm{E}$ that presented NASH proven via biopsy had significant histological improvement. ${ }^{24}$

Some data suggests potential safety concerns with the long-term use of vitamin $\mathrm{E}$, though. A meta-analysis that included 11 trials that tested the effect of vitamin $\mathrm{E}$ supplementation in humans showed that high-dose supplementation (400 U/day) was associated with increased mortality due to any cause..$^{25}$

\section{Cytoprotective agents}

Drugs classified as cytoprotective agents prevent apoptosis and inhibit the inflammatory cascade, two central mechanisms in the pathogenesis of NASH.

\section{Ursodeoxycholic acid}

Ursodeoxycholic acid (UDCA) is an excellent example of a cytoprotective agent that has been investigated in the treatment of NASH. The largest study that evaluated UDCA versus a placebo showed similar improvement in both groups, despite a high dropout rate and an unexpectedly high rate of improvement in the placebo group. ${ }^{26} \mathrm{~A}$ randomized and controlled study with 147 patients treated with a placebo versus UDCA at $23-28 \mathrm{mg} / \mathrm{kg} /$ day only found an improvement of ALT serum levels and lobular inflammation, with the absence of a significant overall histological improvement. ${ }^{27}$ A study of 126 patients comparing high doses of UDCA with a placebo showed an improvement in the level of aminotransferase, serum markers of fibrosis (FibroTest) and IR after 12 months, although liver histology was not assessed. ${ }^{28}$ These controversial results, associated with recent concerns about the increased mortality from all causes with high doses of UDCA in primary sclerosing cholangitis has led to a decrease in research with patients with NAFLD.

\section{Pentoxifylline}

Another approach to the treatment of NAFLD involves using anti-TNF- $\alpha$ drugs, given that this cytokine induces both necroinflammation as well as IR. ${ }^{29}$ Pentoxifylline is a TNF- $\alpha$ inhibitor, and has been used in animal models ${ }^{30}$ and in patients with NASH. A meta-analysis assessing five randomized, placebo-controlled studies, including only 157 patients, showed that pentoxifylline can reduce transaminase activity and improve histological parameters in NAFLD patients. ${ }^{31}$

A more recent study not included in this meta-analysis and involving $55 \mathrm{NASH}$ patients showed an average improvement of 1.6 points in the NAS score $v$ s. 0.1 points in the placebo group. The reduction in fibrosis was not statistically significant, although it occurred in $35 \%$ of patients in the pentoxifylline group $v$ s. $15 \%$ in the placebo group. ${ }^{32}$ Therapy with this medication appears to be well tolerated, although other studies are needed before it can be recommended as a therapy for NASH.

\section{HyPOLIPIDEMIC AGENTS}

Hypolipidemic medication such as statins and omega-3 fatty acids are seen as potential options for the treatment of NAFLD due to their effects on hypertriglyceridemia and low levels of HDL cholesterol, which are common changes in patients with MetS.

\section{Statins}

With antioxidant and anti-inflammatory properties, in addition to the frequent coexistence of NAFLD and dyslipidemia, and the increased cardiovascular risk of these patients, statins appear as an attractive therapeutic option 
in NAFLD. Important evidence indicates the use of statins in order to reduce cardiovascular disease in patients with dyslipidemia. ${ }^{33}$ However, data on the effectiveness of statins for the treatment of NAFLD is scarce. A pilot study in which 16 participants with NASH proven via biopsy were randomized to receive $40 \mathrm{mg}$ of simvastatin or a placebo for 12 months found a significant improvement in the level of aminotransferase in the simvastatin group. Liver histology was not significantly affected by the simvastatin. ${ }^{34}$ Similarly, another study using atorvastatin $24 \mathrm{mg} /$ day versus a placebo revealed that there was a significant improvement in serum transaminase in the statins group. Furthermore, there was an increase in aminotransferase in the placebo group. Histological changes were not assessed. ${ }^{35}$ At the present time, when there is still a lack of evidence of any histological benefit, therapy with statins may not be recommended as a primary therapy for NAFLD but as a treatment for associated hyperlipidemia.

\section{0mega-3 fatty acids}

Omega 3 fatty acids, especially eicosapentaenoic acid (EPA) and docosahexaenoic acid (DHA), are potent activators of nuclear receptor proteins such as PPAR $\alpha$ and $\operatorname{PPAR} \gamma$, which regulate various genes involved in the stimulation of fatty acid oxidation, regulate pro-inflammatory genes, such as TNF- $\alpha$ and IL- 6 , and improve insulin sensitivity. ${ }^{36,37}$ In relation to the effects on NAFLD, a recent systematic review and meta-analysis found heterogeneity between the studies and concluded that, although omega-3 supplementation may decrease fat in the liver (without effects on transaminase levels), the optimal dose has not yet been established. ${ }^{38} \mathrm{~A}$ subsequent randomized, double-blind study assessed supplementation with an EPA compound in individuals with NASH confirmed via biopsy. After 12 months, there was no improvement in the histological characteristics of the NASH. A possible explanation for the negative results of this study is that the dose of EPA was not sufficiently suitable for the population (only $2.7 \mathrm{~g} /$ day). Furthermore, the response rate to the placebo in this trial was higher than previously reported in other studies. ${ }^{39}$ Thus, additional studies are needed to support the routine use of omega-3 in patients with NAFLD, with its use currently restricted to the treatment of hypertriglyceridemia.

\section{INSULIN SENSITIZERS}

Given the importance of IR in the pathogenesis of NASH, insulin sensitizers such as metformin and thiazolidinedio- nes (TZDs) have been extensively studied in the treatment of NASH.

\section{Metformin}

Metformin is a biguanide that improves IR and hyperinsulinemia by reducing hepatic glucose production, increasing peripheral glucose uptake by the muscles and reversing IR induced by tumor necrosis factor. ${ }^{40}$ However, recent meta-analyses have concluded that the use of metformin did not promote a consistent benefit in patients with hepatic steatosis. ${ }^{41,42}$ Therefore, its use is reserved for the management of patients with fatty liver and associated type 2 diabetes as it improves the metabolic parameters and promotes moderate weight loss. ${ }^{43}$

\section{Thiazolidinediones}

Thiazolidinediones improve insulin sensitivity in adipose tissue, activating nuclear transcription factor PPAR $\gamma{ }^{44}$ The two drugs in this class that have been studied in the treatment of NASH are pioglitazone and rosiglitazone. A series of well-designed randomized clinical trials has shown the efficacy of these medications in the improvement of fatty liver, inflammation, cell ballooning, and possibly fibrosis. ${ }^{45-47}$

In the multicenter, randomized PIVENS (Study of Pioglitazone versus Vitamin E versus Placebo for the Treatment of Non-Diabetic Patients with Hepatic Steatosis) study, 247 adults with NASH and without diabetes were randomized to receive one of three treatments (placebo, $\mathrm{n}=83$; vitamin E $800 \mathrm{IU} /$ day, $\mathrm{n}=84$, or pioglitazone $30 \mathrm{mg} /$ day, $n=80$ ) for 96 weeks. Although pioglitazone did not achieve its main objective, it improved insulin sensitivity and decreased steatohepatitis (34 vs. 19\%; $\mathrm{p}=0.04$ ) compared to the placebo. ${ }^{23} \mathrm{~A}$ recent meta-analysis assessing four randomized clinical trials (three with pioglitazone and one with rosiglitazone) showed improvement in steatosis, inflammation and cell ballooning, but no improvement in fibrosis. However, by limiting the analysis to studies with pioglitazone, a significant improvement in fibrosis is observed (OR 1.68, 95CI 1.02-2.77). ${ }^{48}$

TZD therapy is not free of side effects, which may limit its clinical usefulness. Both pioglitazone and rosiglitazone are associated with an average weight gain of 3 to $4 \mathrm{~kg}$ with long-term treatment, and retrospective assessments have linked TZD therapy to decreased bone mineral density and fractures. ${ }^{49}$ Recent evidence has associated the use of rosiglitazone with increased rates of myocardial infarction, which has reduced this agent being indicated as a therapeutic option. ${ }^{50,51}$ However, piogli- 
tazone remains available and is considered as a potential treatment for patients with NASH.

\section{NEW APPROACHES AND TREATMENT SUMMARY}

Obeticolic acid

Obeticolic acid (OCA), a derivative of chenodeoxycholic acid, is a selective agonist of the farnesoid X receptor (FXR), which is a nuclear hormone receptor that regulates glucose and lipid metabolism. Several preclinical studies have shown that OCA increases sensitivity to insulin and regulates glucose homeostasis, modulates lipid metabolism, and exerts anti-inflammatory and fibrotic effects on the liver, kidney and intestine, the main organs expressing FXR. ${ }^{52}$

A recent multicenter, double-blind, controlled and randomized study has evaluated the effectiveness of OCA in non-cirrhotic NASH patients. Patients were randomly distributed 1:1 to receive the treatment administered orally with OCA ( $25 \mathrm{mg} /$ day) or a placebo for 72 weeks. OCA was associated with improvement of the histologi- cal characteristics of NASH in comparison with the placebo. ${ }^{53}$ More studies are required to prove the benefits of this drug in the long term and its actual safety, especially in relation to changes in the lipid profile.

Table 2 presents the main options for the treatment of NAFLD.

\section{Conclusion}

Lifestyle intervention remains the cornerstone of NAFLD treatment. However, it is well recognized that lifestyle changes in diet and exercise are difficult to achieve and maintain in the long term. Current guidelines recommend that pioglitazone and vitamin $\mathrm{E}$ may be used to treat steatohepatitis in non-diabetic patients, despite inconclusive data about their long-term safety. Other conditions associated with NAFLD must also be controlled, such as diabetes mellitus and dyslipidemia. Large studies should be performed to better assess the efficacy and safety of antioxidant or cytoprotective drugs and to find possible

TABLE 2 Treatment options in non-alcoholic fatty liver disease.

\begin{tabular}{|c|c|c|}
\hline Modality & Effect & Comments \\
\hline \multicolumn{3}{|l|}{ Diet } \\
\hline $\begin{array}{l}\text { Weight loss of } 5-10 \% \text {. Moderate calorie } \\
\text { restriction. Reduce } 500-750 \mathrm{kcal} / \text { day }\end{array}$ & Improves histology in NASH & $\begin{array}{l}\text { Only } 40 \% \text { of patients are able to achieve these goals. A } \\
\text { loss of at least } 10 \% \text { is necessary to decrease fibrosis }\end{array}$ \\
\hline $\begin{array}{l}\text { Eliminate or significantly reduce saturated fats } \\
\text { and fructose in the diet }\end{array}$ & $\begin{array}{l}\text { Fructose increases lipogenesis } \\
\text { through activation of pyruvate } \\
\text { dehydrogenase }\end{array}$ & $\begin{array}{l}\text { Prospective studies have shown that fructose } \\
\text { consumption is a risk factor for NAFLD }\end{array}$ \\
\hline Consider omega- 3 supplementation & $\begin{array}{l}\text { May decrease hepatic steatosis. } \\
\text { Decreases triglyceride levels }\end{array}$ & $\begin{array}{l}\text { The optimal dose is unclear, but some benefit may be } \\
\text { achieved with a dose of } 1 \mathrm{~g} / \text { day }\end{array}$ \\
\hline \multicolumn{3}{|l|}{ Physical activity } \\
\hline$\geq 250 \mathrm{~min} /$ week & $\begin{array}{l}\text { Decreases insulin resistance and } \\
\text { decreases hepatic steatosis }\end{array}$ & $\begin{array}{l}\text { Benefits with aerobic or anaerobic physical activity. } \\
\text { Best results associated with diet }\end{array}$ \\
\hline \multicolumn{3}{|l|}{ Pharmacological treatment } \\
\hline Vitamin E $800 \mathrm{IU} /$ day & Improves histology in NASH & $\begin{array}{l}\text { Benefits must be validated in diabetics and various } \\
\text { ethnic groups. May increase the risk of prostate cancer }\end{array}$ \\
\hline Pioglitazone 30 mg/day & Improves histology in NASH & $\begin{array}{l}\text { Associated with weight gain. Possible increased risk of } \\
\mathrm{CHF} \text { and osteoporosis }\end{array}$ \\
\hline Metformin & $\begin{array}{l}\text { Improves metabolic parameters } \\
\text { and promote moderate weight loss }\end{array}$ & $\begin{array}{l}\text { No direct improvement in NAFLD. Its use is reserved } \\
\text { for the management of patients with fatty liver and } \\
\text { associated type } 2 \text { diabetes }\end{array}$ \\
\hline Statins & $\begin{array}{l}\text { Limited data relating to histological } \\
\text { improvement }\end{array}$ & $\begin{array}{l}\text { Safe in patients with NAFLD. Decreases the risk of } \\
\text { cardiovascular diseases }\end{array}$ \\
\hline \multicolumn{3}{|l|}{ Bariatric surgery } \\
\hline $\begin{array}{l}\text { Roux-en-Y gastric bypass; adjustable gastric } \\
\text { band; vertical gastrectomy }\end{array}$ & $\begin{array}{l}\text { Improves histology in NASH in up } \\
\text { to } 80 \% \text { cases, including fibrosis }\end{array}$ & $\begin{array}{l}\text { Few randomized and controlled studies; caution in } \\
\text { patients with cirrhosis; lifestyle change should be } \\
\text { attempted first }\end{array}$ \\
\hline
\end{tabular}


medication that could directly affect the pathophysiology of hepatic steatosis.

\section{Resumo}

Atualidades no tratamento da doença hepática gordurosa não alcoólica

A doença hepática gordurosa não alcoólica (DHGNA) é caracterizada pela deposição significativa de lipídios nos hepatócitos de pacientes que não apresentam história de ingestão alcoólica significativa. É a doença do fígado mais prevalente em populações ocidentais e existe forte associação da DHGNA com a resistência à insulina (RI) e com a síndrome metabólica. O tratamento objetiva reduzir a RI, o estresse oxidativo, a obesidade, a dislipidemia bem como a inflamação e a fibrose hepáticas. O tratamento atual baseia-se principalmente em modificações do estilo de vida, que incluem dieta e prática regular de exercícios físicos, associadas ao tratamento de todos os componentes da síndrome metabólica. Quanto ao tratamento medicamentoso da esteato-hepatite não alcoólica, os agentes insulino-sensibilizantes e os antioxidantes parecem os mais promissores, especialmente as tiazolidinodionas e a vitamina $\mathrm{E}$, mas faltam estudos multicêntricos avaliando sua segurança a longo prazo.

Palavras-chave: hepatopatia gordurosa não alcoólica, esteatose hepática, esteato-hepatite, síndrome metabólica, obesidade.

\section{References}

1. Ballestri S, Zona S, Targher G, Romagnoli D, Baldelli E, Nascimbeni F, et al. Nonalcoholic fatty liver disease is associated with an almost two-fold increased risk of incident type 2 diabetes and metabolic syndrome. Evidence from a systematic review and meta-analysis. J Gastroenterol Hepatol. 2016; 31(5):936-44

2. Unwin N. The metabolic syndrome. J R Soc Med. 2006; 99(9):457-62.

3. Birkenfeld AL, Shulman GI. Nonalcoholic fatty liver disease, hepatic insulin resistance, and type 2 diabetes. Hepatology. 2014; 59(2):713-23.

4. Younossi ZM. Review article: current management of non-alcoholic fatty liver disease and non-alcoholic steatohepatitis. Aliment Pharmacol Ther. 2008; 28(1):2-12.

5. Torres DM, Williams CD, Harrison SA. Features, diagnosis, and treatment of nonalcoholic fatty liver disease. Clin Gastroenterol Hepatol. 2012; 10(8):837-58.

6. Bellentani S, Dalle Grave R, Suppini A, Marchesini G; Fatty Liver Italian Network. Behavior therapy for nonalcoholic fatty liver disease: The need for a multidisciplinary approach. Hepatology. 2008; 47(2):746-54.

7. Krasnoff JB, Painter PL, Wallace JP, Bass NM, Merriman RB. Health-related fitness and physical activity in patients with nonalcoholic fatty liver disease. Hepatology. 2008; 47(4):1158-66.

8. Oh S, Shida T, Yamagishi K, Tanaka K, So R, Tsujimoto T, et al. Moderate to vigorous physical activity volume is an important factor for managing nonalcoholic fatty liver disease: a retrospective study. Hepatology. 2015; 61(4):1205-15.
9. Sreenivasa Baba C, Alexander G, Kalyani B, Pandey R, Rastogi S, Pandey A, et al. Effect of exercise and dietary modification on serum aminotransferase levels in patients with nonalcoholic steatohepatitis. J Gastroenterol Hepatol. 2006; 21(1 Pt 1):191-8.

10. Thamer C, Machann J, Stefan N, Haap M, Schäfer S, Brenner S, et al. High visceral fat mass and high liver fat are associated with resistance to lifestyle intervention. Obesity (Silver Spring). 2007; 15(2):531-8.

11. Albu JB, Heilbronn LK, Kelley DE, Smith SR, Azuma K, Berk ES, et al.; Look AHEAD Adipose Research Group. Metabolic changes following a 1-year diet and exercise intervention in patients with type 2 diabetes. Diabetes. 2010; 59(3):627-33

12. Promrat K, Kleiner DE, Niemeier HM, Jackvony E, Kearns M, Wands JR, et al. Randomized controlled trial testing the effects of weight loss on nonalcoholic steatohepatitis. Hepatology. 2010; 51(1):121-9.

13. Lazo M, Solga SF, Horska A, Bonekamp S, Diehl AM, Brancati FL, et al.; Fatty Liver Subgroup of the Look AHEAD Research Group. Effect of a 12-month intensive lifestyle intervention on hepatic steatosis in adults with type 2 diabetes. Diabetes Care. 2010; 33(10):2156-63.

14. Vilar-Gomez E, Martinez-Perez Y, Calzadilla-Bertot L, Torres-Gonzalez A, Gra-Oramas B, Gonzalez-Fabian L, et al. Weight loss via lifestyle modification significantly reduces features of nonalcoholic steatohepatitis. Gastroenterology. 2015; 149(2):367-78.e5.

15. Schauer PR, Kashyap SR, Wolski K, Brethauer SA, Kirwan JP, Pothier CE, et al. Bariatric surgery versus intensive medical therapy in obese patients with diabetes. N Engl J Med. 2012; 336(17):1567-76.

16. Schauer PR, Bhatt DL, Kirwan JP, Wolski K, Brethauer SA, Navaneethan $\mathrm{SD}$, et al. Bariatric surgery versus intensive medical therapy for diabetes 3-year outcomes. N Engl J Med. 2014; 370(21):2002-13.

17. Mummadi RR, Kasturi KS, Chennareddygari S, Sood GK. Effect of bariatric surgery on nonalcoholic fatty liver disease: systematic review and metaanalysis. Clin Gastroenterol Hepatol. 2008; 6(12):1396-402.

18. Stephen S, Baranova A, Younossi ZM. Nonalcoholic fatty liver disease and bariatric surgery. Expert Rev Gastroenterol Hepatol. 2012; 6(2):163-71.

19. Hafeez S, Ahmed MH. Bariatric surgery as potential treatment for nonalcoholic fatty liver disease: a future treatment by choice or by chance? J Obes. 2013; 2013:839275.

20. Bower G, Toma T, Harling L, Jiao LR, Efthimiou E, Darzi A, et al. Bariatric surgery and non-alcoholic fatty liver disease: a systematic review of liver biochemistry and histology. Obes Surg. 2015; 25(12):2280-9.

21. Lassailly G, Caiazzo R, Buob D, Pigeyre M, Verkindt H, Labreuche J, et al. Bariatric surgery reduces features of non-alcoholic steatohepatitis in morbidly obese patients. Gastroenterology. 2015; 149(2):379-88.

22. Chavez-Tapia NC, Tellez-Avila FI, Barrientos-Gutierrez T, Mendez-Sanchez N, Lizardi-Cervera J, Uribe M. Bariatric surgery for non-alcoholic steatohepatitis in obese patients. Cochrane Database Syst Rev. 2010; (1):CD007340.

23. Sanyal AJ, Chalasani N, Kowdley K V, McCullough A, Diehl AM, Bass NM, et al.; NASH CRN. Pioglitazone, vitamin E, or placebo for nonalcoholic steatohepatitis. N Engl J Med. 2010; 362(18):1675-85

24. Lavine JE, Schwimmer JB, Van Natta ML, Molleston JP, Murray KF, Rosenthal P, et al.; Nonalcoholic Steatohepatitis Clinical Research Network. Effect of vitamin $\mathrm{E}$ or metformin for treatment of nonalcoholic fatty liver disease in children and adolescents: the TONIC randomized controlled trial. JAMA. 2011; 305(16):1659-68.

25. Miller ER 3rd, Pastor-Barriuso R, Dalal D, Riemersma RA, Appel LJ, Guallar E. Meta-analysis: High-dosage vitamin E supplementation may increase allcause mortality. Ann Intern Med. 2005; 142(1):37-46.

26. Lindor KD, Kowdley K V, Heathcote EJ, Harrison ME, Jorgensen R, Angulo $\mathrm{P}$, et al. Ursodeoxycholic acid for treatment of nonalcoholic steatohepatitis: results of a randomized trial. Hepatology. 2004; 39(3):770-8.

27. Leuschner UFH, Lindenthal B, Herrmann G, Arnold JC, Rössle M, Cordes $\mathrm{H}-\mathrm{J}$, et al.; NASH Study Group. High-dose ursodeoxycholic acid therapy for nonalcoholic steatohepatitis: a double-blind, randomized, placebo-controlled trial. Hepatology. 2010; 52(2):472-9.

28. Ratziu V, De Ledinghen V, Oberti F, Mathurin P, Wartelle-Bladou C, Renou C, et al.; FRESGUN. A randomized controlled trial of high-dose ursodesoxycholic acid for nonalcoholic steatohepatitis. J Hepatol. 2011; 54(5):1011-9

29. Musso G, Gambino R, Cassader M, Pagano G. A meta-analysis of randomized trials for the treatment of nonalcoholic fatty liver disease. Hepatology. 2010; 52(1):79-104 
30. Zaitone S, Hassan N, El-Orabi N, El-Awady el-S. Pentoxifylline and melatonin in combination with pioglitazone ameliorate experimental non-alcoholic fatty liver disease. Eur J Pharmacol. 2011; 662(1-3):70-7.

31. Zeng T, Zhang CL, Zhao XL, Xie KQ. Pentoxifylline for the treatment of nonalcoholic fatty liver disease: a meta-analysis of randomized double-blind, placebo-controlled studies. Eur J Gastroenterol Hepatol. 2014; 26(6):646-53.

32. Zein CO, Yerian LM, Gogate P, Lopez R, Kirwan JP, Feldstein AE, et al. Pentoxifylline improves nonalcoholic steatohepatitis: a randomized placebocontrolled trial. Hepatology. 2011; 54(5):1610-9.

33. Cholesterol Treatment Trialists' (CTT) Collaboration, Fulcher J, O'Connell R, Voysey M, Emberson J, Blackwell L, et al. Efficacy and safety of LDLlowering therapy among men and women: meta-analysis of individual data from 174,000 participants in 27 randomised trials. Lancet. 2015; 385(9976):1397-405.

34. Eslami L, Merat S, Malekzadeh R, Nasseri-Moghaddam S, Aramin H. Statins for non-alcoholic fatty liver disease and non-alcoholic steatohepatitis. Cochrane Database Syst Rev. 2013; 12(12):CD008623.

35. Athyros VG, Tziomalos K, Gossios TD, Griva T, Anagnostis P, Kargiotis K, et al.; GREACE Study Collaborative Group. Safety and efficacy of long-term statin treatment for cardiovascular events in patients with coronary heart disease and abnormal liver tests in the Greek Atorvastatin and Coronary Heart Disease Evaluation (GREACE) Study: a post-hoc analysis. Lancet. 2010; 376(9756):1916-22.

36. Brown JD, Plutzky J. Peroxisome proliferator-activated receptors as transcriptional nodal points and therapeutic targets. Circulation. 2007; 115(4):518-33.

37. Stienstra R, Mandard S, Patsouris D, Maass C, Kersten S, Müller M. Peroxisome proliferator-activated receptor $\otimes$ protects against obesity-induced hepatic inflammation. Endocrinology. 2007; 148(6):2753-63.

38. Parker HM, Johnson NA, Burdon CA, Cohn JS, O’Connor HT, George J. Omega-3 supplementation and non-alcoholic fatty liver disease: a systematic review and meta-analysis. J Hepatol. 2012; 56(4):944-51.

39. Sanyal AJ, Abdelmalek MF, Suzuki A, Cummings OW, Chojkier M; EPE-A Study Group. No significant effects of ethyl-eicosapentanoic acid on histologic features of nonalcoholic steatohepatitis in a phase 2 trial. Gastroenterology. 2014; 147(2):377-84.e1.

40. Rouabhia S, Milic N, Abenavoli L. Metformin in the treatment of non alcoholic fatty liver disease: safety, efficacy and mechanism. Expert Rev Gastroenterol Hepatol. 2014; 8(4):343-9.
41. Li Y, Liu L, Wang B, Wang J, Chen D. Metformin in non-alcoholic fatty liver disease: a systematic review and meta-analysis. Biomed Rep. 2013; 1(1):57-64.

42. Musso G, Cassader M, Rosina F, Gambino R. Impact of current treatments on liver disease, glucose metabolism and cardiovascular risk in non-alcoholic fatty liver disease (NAFLD): a systematic review and meta-analysis of randomised trials. Diabetologia. 2012; 55(4):885-904.

43. Krakoff J, Clark JM, Crandall JP, Wilson C, Molitch ME, Brancati FL, et al.; Diabetes Prevention Program Research Group. Effects of metformin and weight loss on serum alanine aminotransferase activity in the diabetes prevention program. Obesity (Silver Spring). 2010; 18(9):1762-7.

44. Yki-Järvinen H. Thiazolidinediones. N Engl J Med. 2004; 351(11):1106-18

45. Belfort R, Harrison SA, Brown K, Darland C, Finch J, Hardies J, et al. A placebo-controlled trial of pioglitazone in subjects with nonalcoholic steatohepatitis. N Engl J Med. 2006; 355(22):2297-307.

46. Aithal GP, Thomas JA, Kaye PV, Lawson A, Ryder SD, Spendlove I, et al. Randomized, placebo-controlled trial of pioglitazone in nondiabetic subjects with nonalcoholic steatohepatitis. Gastroenterology. 2008; 135(4):1176-84

47. Ratziu V, Charlotte F, Bernhardt C, Giral P, Halbron M, Lenaour G, et al.; LIDO Study Group. Long-term efficacy of rosiglitazone in nonalcoholic steatohepatitis: results of the Fatty Liver Improvement by Rosiglitazone Therapy (FLIRT 2) extension trial. Hepatology. 2010; 51(2):445-53.

48. Boettcher E, Csako G, Pucino F, Wesley R, Loomba R. Meta-analysis: pioglitazone improves liver histology and fibrosis in patients with nonalcoholic steatohepatitis. Aliment Pharmacol Ther. 2012; 35(1):66-75.

49. Murphy CE, Rodgers PT. Effects of thiazolidinediones on bone loss and fracture. Ann Pharmacother. 2007; 41(12):2014-8.

50. Nissen SE, Wolski K. Effect of rosiglitazone on the risk of myocardial infarction and death from cardiovascular causes. N Engl J Med. 2007; 356(24):2457-71.

51. Singh S, Loke YK, Furberg CD. Long-term risk of cardiovascular events with rosiglitazone: a meta-analysis. JAMA. 2007; 298(10):1189-95.

52. Adorini L, Pruzanski M, Shapiro D. Farnesoid X receptor targeting to treat nonalcoholic steatohepatitis. Drug Discov Today. 2012; 17(17-18):988-97.

53. Neuschwander-Tetri BA, Loomba R, Sanyal AJ, Lavine JE, Van Natta ML, Abdelmalek MF, et al.; NASH Clinical Research Network. Farnesoid X nuclear receptor ligand obeticholic acid for non-cirrhotic, non-alcoholic steatohepatitis (FLINT): a multicentre, randomised, placebo-controlled trial. Lancet. 2015; 385(9972):956-65. 